2021-01-01

\title{
Environmental concentrations of antifouling paint particles are toxic to sediment-dwelling invertebrates
}

\section{Muller-Karanassos, C}

http://hdl.handle.net/10026.1/16665

\subsection{6/j.envpol.2020.115754}

Environmental Pollution

Elsevier

All content in PEARL is protected by copyright law. Author manuscripts are made available in accordance with publisher policies. Please cite only the published version using the details provided on the item record or document. In the absence of an open licence (e.g. Creative Commons), permissions for further reuse of content should be sought from the publisher or author. 
Environmental concentrations of antifouling paint particles are toxic to sediment-dwelling

2 invertebrates

3 Christina Muller-Karanassos ${ }^{1,2 *}$, William Arundel ${ }^{1,2 ₹}$, Penelope K Lindeque ${ }^{2}$, Tom Vance ${ }^{3}$, Andrew Turner ${ }^{4}$

4 \& Matthew Cole ${ }^{2 *}$

$83 \mathrm{DH}, \mathrm{UK}$

9 3PML Applications, Prospect Place, Plymouth, PL1 3DH, UK

$10{ }^{4}$ School of Geography, Earth and Environmental Sciences, University of Plymouth, Drake Circus, Plymouth,

11 PL4 8AA, UK

$12 \quad{ }^{¥}$ joint first authors

13 *Corresponding author: MC; Email: mcol@pml.ac.uk; Telephone: +44 (0)1752 633100

14 https://doi.org/10.1016/j.envpol.2020.115754

15 Accepted September 2020

\section{Abstract}

17 Antifouling paint particles (APPs) and associated metals have been identified in sediments around 18 boatyards and marinas globally, but the effects of APPs on benthic organisms are largely unknown. Sub19 lethal endpoints were measured following laboratory exposures of the harbour ragworm (Hediste 20 diversicolor) and the common cockle (Cerastoderma edule) to environmentally relevant concentrations of 21 biocidal ('modern' and 'historic') and biocide-free ('silicone') APPs added to clean estuarine sediment. 22 Further, the 5-day median lethal concentrations $\left(\mathrm{LC}_{50}\right)$ and effects concentrations (EC $\left.\mathrm{C}_{50}\right)$ for modern 23 biocidal APPs were calculated. For ragworms, significant decreases in weight $(15.7 \% ; p<0.01)$ and feeding 24 rate $(10.2 \% ; p<0.05)$ were observed in the modern biocidal treatment; burrowing behaviour was also 25 reduced by $29 \%$ in this treatment, but was not significant. For cockles, the modern biocidal treatment led 26 to $100 \%$ mortality of all replicates before endpoints were measured. In cockles, there was elevated levels 27 of metallothionein-like protein (MTLP) in response to both modern and historic biocidal treatments. 28 Ragworms had a higher tolerance to modern APPs (5-day $\mathrm{LC}_{50}: 19.9 \mathrm{APP} \mathrm{g} \mathrm{L}^{-1} ; \mathrm{EC}_{50}: 14.6 \mathrm{~g} \mathrm{~L}^{-1}$ ) compared to 29 cockles (5-day $\mathrm{LC}_{50}: 2.3 \mathrm{~g} \mathrm{~L}^{-1}$ and $\mathrm{EC}_{50}: 1.4 \mathrm{~g} \mathrm{~L}^{-1}$ ). The results of this study indicate that modern biocidal 30 APPs, containing high $\mathrm{Cu}$ concentrations, have the potential to adversely affect the health of benthic 31 organisms at environmentally relevant concentrations. The findings highlight the need for stricter 32 regulations on the disposal of APP waste originating from boatyards, marinas and abandoned boats. 


\section{Graphical abstract}

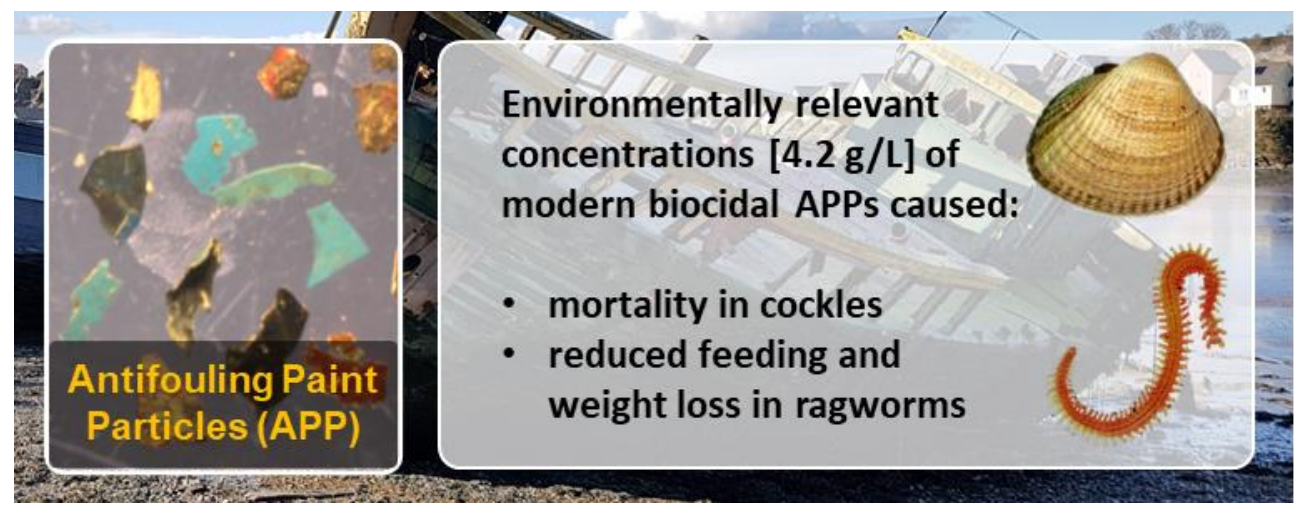

Keywords: Microplastic, Fouling, Biocidal, Toxicity, Copper

Highlights

- Antifouling paint particles (APPs) are a type of microplastic debris

- Biocidal APPs containing copper proved toxic to sediment-dwelling biota

- Biocidal APPs were toxic at environmentally relevant concentrations

- Non-biocidal silicone-based APPs showed little toxicity

\section{Capsule}

47 In contrast to non-biocidal silicone formulations, copper-based biocidal antifouling paint particles (APPs) proved toxic to cockles and ragworms at environmentally relevant concentrations.

\section{Introduction}

Antifouling paint is widely applied to marine structures to reduce biofouling, with the antifouling

52 paints and coatings market estimated to be worth US\$9.22 billion by 2021 (Markets, 2016). Biofouling of

53 submerged marine structures can lead to increased frictional drag, reduced manoeuvrability of marine

54 vessels, higher fuel consumption and increased cleaning and maintenance costs (Chambers et al., 2006;

55 Yebra et al., 2004). Antifouling coatings typically work by leaching biocides into the surrounding seawater

56 and forming a protective microlayer (Nurioglu et al., 2015; Singh and Turner, 2009a). Following the

57 worldwide ban on organotin-based antifouling paints (e.g. tributyltin) in 2008, owing to toxic effects on 
non-target organisms (Evans et al., 1995; IMO, 2018), new tin-free antifouling paints were developed

59 (Yebra et al., 2004). Most contemporary biocidal antifouling paints contain $\mathrm{Cu}(\mathrm{I})$ as the main biocide, in 60 the form of cuprous oxide $\left(\mathrm{Cu}_{2} \mathrm{O}\right)$ or copper thiocyanate ( $\left.\mathrm{CuSCN}\right)$, in combination with $\mathrm{Zn}$-based 61 compounds such as zinc oxide (ZnO) (Turner, 2010); booster biocides such as zinc pyrithione (ZnPT), Irgarol 621051 and diuron are also added to antifouling formulations to increase their effectiveness (Turner, 2010). 63 Owing to their toxicity to marine life, a range of biocide-free antifouling formulations are also currently 64 being developed. For example, silicone coatings work by reducing the adhesion of organisms to the 65 surface of boats (Almeida et al., 2007) and have been found to be less toxic to marine organisms (Karlsson 66 and Eklund, 2004).

67 Antifouling paint particles (APPs) are waste products, generated in boatyards and marinas during 68 maintenance and cleaning of boat hulls and grounded ships and boats (uurner, 2010). The disposal of APP 69 waste is largely unregulated in the recreational boating industry and APPs can be readily transported from 70 hard-standings and slipways into the marine environment via run-off (Connelly et al., 2001; Thomas et al., 71 2003; Turner, 2010) (Figure 1). APPs also originate from weathering of old abandoned boats, which are 72 often coated in numerous layers of historic antifouling paint and may contain banned or restricted 73 compounds such as TBT and metals like $\mathrm{Pb}$, historically used in antifouling and non-antifouling marine 74 paints (Rees et al., 2014; Turner, 2010). Fine APP particulates might also be aerially dispersed, as observed 75 with microfibres (Liu et al., 2019). APPs are highly heterogeneous in their chemical make-up, owing to the 76 variety of antifouling formulations used over the past fifty years (Sandberg et al., 2007; $\underline{\text { Turner, 2010). }}$ 77 Once in the marine environment, APPs can accumulate in benthic sediments around marinas, boatyards 78 and abandoned boats; in the Plym estuary (UK), sampling revealed APP concentrations of 430 particles L$79{ }^{1}\left(0.2 \mathrm{~g} \mathrm{~L}^{-1}\right)$ next to a boat maintenance facility and 400 particles $\mathrm{L}^{-1}\left(4.2 \mathrm{~g} \mathrm{~L}^{-1}\right)$ in an area containing 80 abandoned boats (Muller-Karanassos et al., 2019). APPs continue to leach biocides into the surrounding 81 environment, with several studies finding high metal concentrations, often exceeding environmental 82 standards, in sediments contaminated with APPs (Eklund et al., 2014; Muller-Karanassos et al., 2019; $\underline{\text { Rees }}$ 83 et al., 2014; Sapozhnikova et al., 2013; Singh and Turner, 2009b; Soroldoni et al., 2018a). Biological activity 84 (e.g. bioturbation, bioirrigation) has the capacity to redistribute and resuspend particles and metals

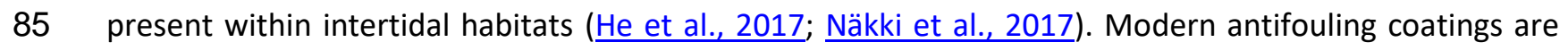
86 polymeric with an alkyd resin base (Toben, 2017) and as such, APPs can be considered as a type of 87 microplastic (plastic debris, $1 \mu \mathrm{m}$ - $1 \mathrm{~mm}$ in size) (Boucher and Friot, 2017; Hartmann et al., 2019). Studies 88 have shown that microplastic ingestion by marine organisms may lead to a reduction in feeding, 89 reproduction (Cole et al., 2015) and energy reserves (Wright et al., 2013). Owing to their high metal 
90 concentrations, including $\mathrm{Cu}, \mathrm{Zn}, \mathrm{Sn}$ and $\mathrm{Pb}, \mathrm{APPs}$ pose an additional toxic threat to sediment-dwelling

91 biota. Benthic organisms are essential for the functioning of marine coastal ecosystems and play an 92 important role in energy transfer between pelagic and benthic ecosystems. Laboratory studies have 93 shown that exposure to APPs can lead to an accumulation of biocidal metals ( $\mathrm{Cu}$ and $\mathrm{Zn}$ ) in the tissues of 94 benthic marine organisms including the common mussel Mytilus edulis (Turner et al., 2009), the common 95 periwinkle Littorina littorea (Gammon et al., 2009) and the lugworm Arenicola marina (Turner et al., 2008).

96 Uptake of metals is thought to occur through both aqueous exposure to APP leachate and via direct 97 ingestion of APPs, with a recent study finding evidence of APP ingestion by the harbour ragworm Hediste 98 diversicolor collected from contaminated sediments in the Plym estuary (UK) (Muller-Karanassos et al., 99 2019). Exposure to APP leachate has been found to have sub-lethal effects on marine organisms including 100 a reduction in growth, larval development and bioluminescence (Ytreberg et al., 2010). Only three 101 publications - all focussed upon modern biocidal antifouling materials - have considered the direct 102 toxicity of APPs these studies revealed exposure to increasing concentrations of APPs can cause: a 103 decrease in fecundity and survival in the epibenthic copepod Nitokra sp. (Soroldoni et al., 2017); 104 decreased survival rates in pelagic copepods (Molino et al., 2019); and decreased survival in the benthic 105 microcrustaceans Monokalliapseudes schubarti (a tanaid) and Hyalella azteca (an amphipod) (Soroldoni 106 et al., 2020). 


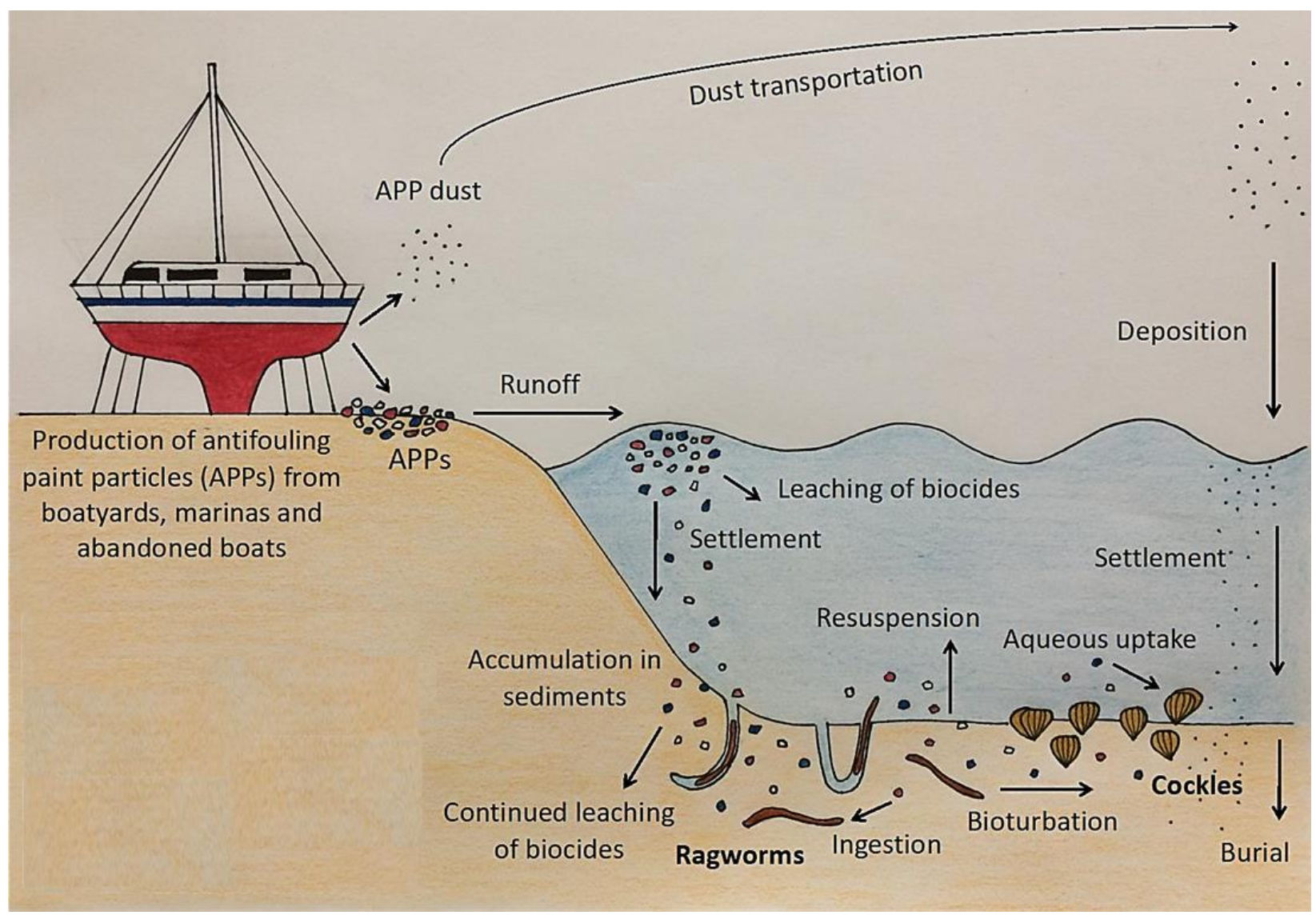

Figure 1. Potential abiotic and biotic transport pathways for antifouling paint particles (APPs) in intertidal habitats.

The aim of this study was to determine if exposure to both biocidal and non-biocidal APPs, at environmentally relevant concentrations, negatively affects the health of benthic organisms with different feeding modes. Two sediment-dwelling estuarine species were chosen for this study, the harbour ragworm, $H$. diversicolor, and the edible cockle, Cerastoderma edule. $H$. diversicolor is a polychaete that is widely distributed in estuaries within Northwest Europe (Budd, 2008), having an important role in estuarine ecosystems as a bioturbator and as a food source for numerous species of wading birds (GossCustard et al., 1989) and flatfish (Budd, 2008). C. edule, is a commercially important species eaten widely throughout Europe and is also an important food source for wading birds and pelagic species in intertidal mudflats, where it can make up a significant proportion of biomass (Romano et al., 2011). Two laboratory studies were conducted: (1) an 18-day exposure to investigate sub-lethal health effects; and, (2) a 5-day assay to calculate how APP concentrations affected mortality (i.e. LC50s). The findings of this study have implications for the health of biodiverse intertidal ecosystems and the management of antifouling waste. 


\subsection{Specimen collection and husbandry}

129 length, 10.5-25 g wet weight) were collected by hand from an intertidal mudflat at Saltram Park (N 50

$13022^{\prime} 43.284^{\prime \prime}$ W $4^{\circ} 6^{\prime} 0.755^{\prime \prime}$ ) located within the Plym Estuary, UK (Figure 1) in June and July 2018 and 131 transported to PML within 1 hour of sampling. There is no boating activity at Saltram Park and a recent 132 field study showed minimal APP and metal contamination at this site (Muller-Karanassos et al., 2019). A 133 salinity of 31.1 was measured at high water using an Oakton SALT 6+ handheld probe. On return to the 134 laboratory, ragworms and cockles were allowed to acclimate for 4-7 days in polypropylene tanks (49 x 35 $135 \times 15 \mathrm{~cm}$ ) containing approximately $5 \mathrm{~cm}$ depth of sieved estuarine sediment $(<1 \mathrm{~mm})$ collected at Saltram 136 Park and $5 \mathrm{~cm}$ depth of aerated filtered seawater (FSW, $0.2 \mu \mathrm{m}$ Millipore filter diluted to 31.1 salinity with 137 Milli-Q water). 


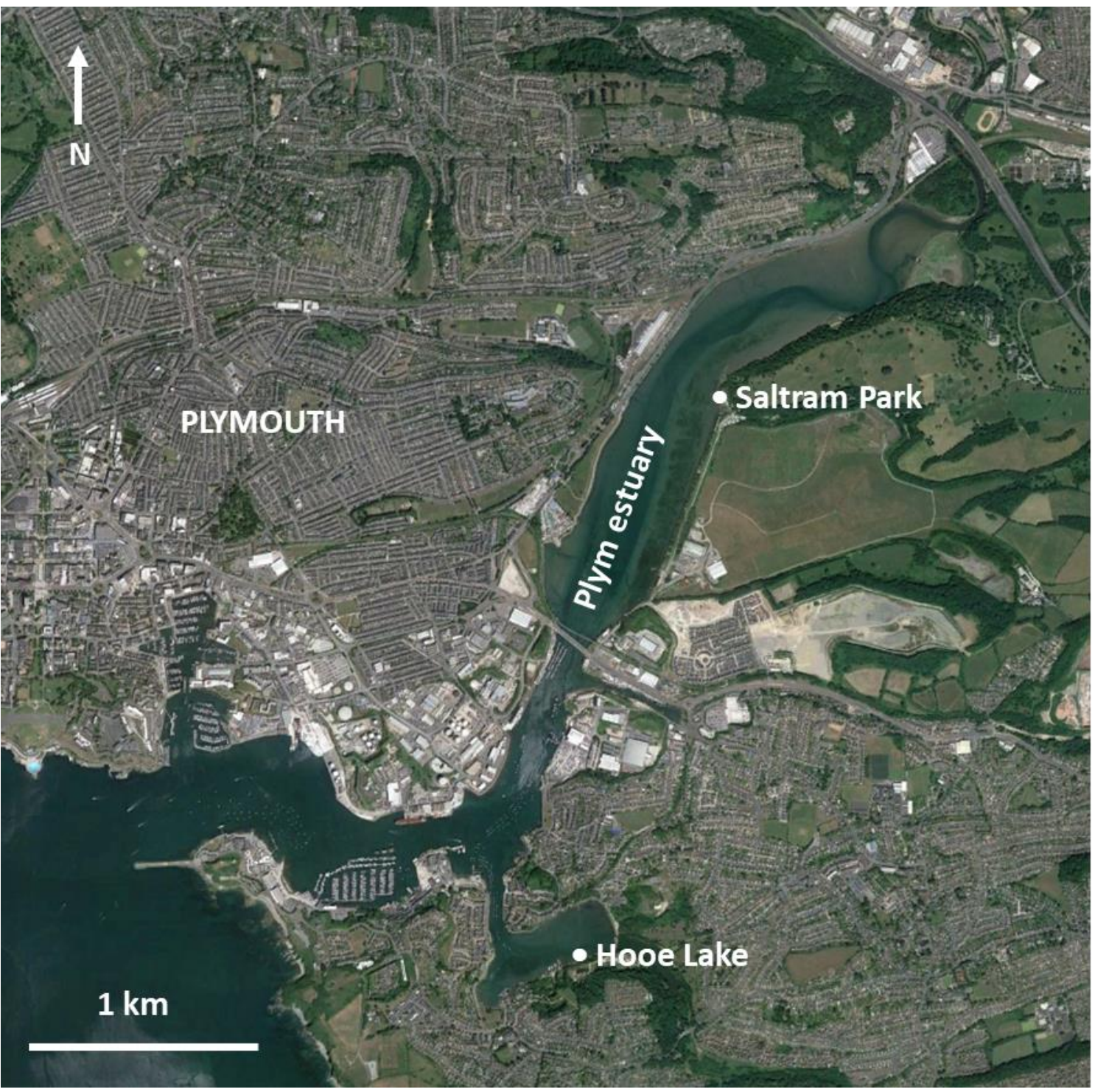

Figure 2. Animals and sediment were collected from Saltram Park, Plym Estuary (UK). Historic APPs were

141 sampled from abandoned boats at Hooe Lake. Map data: Google Earth, Landsat / Copernicus.

\subsection{APP generation and characterisation}

Three types of APPs were generated for use in the exposures, including two biocidal ('historic' and

145 'modern') and one biocide-free ('silicone'). 'Historic' biocidal antifouling paint flakes were collected by 146 hand from abandoned boats at Hooe Lake, in the Plym Estuary (N 50 21' 22.464" W 4 ${ }^{\circ} 6^{\prime}$ 28.943"; Figure 147 2), and cleaned from any visible dirt and algae (Singh and Turner, 2009a). 'Modern' biocidal antifouling 148 paint was scraped off rolled mild steel panels that had been painted with three commercially available 149 biocidal paints in 2012, including an anti-corrosive layer, tie coat and top coat, and submerged in natural 150 seawater off the coast of Orkney (Scotland) for 8 weeks in 2014. Non-biocidal 'silicone' antifouling paint 
was scraped off rolled mild steel panels painted with commercially available silicone paint and submerged

152 in natural seawater for 5-10 days at station L4 (off the coast of Plymouth, UK; 153 www.westernchannelobservatory.co.uk) in 2018. APPs were prepared by grinding down paint flakes using 154 a pestle and mortar with the aid of liquid nitrogen; paint particles were passed through stainless steel 155 sieves to collect the $100 \mu \mathrm{m}-1 \mathrm{~mm}$ fraction, a size range considered bioavailable to the target species and 156 for which APP particles have been identified in estuarine sediments (Muller-Karanassos et al., 2019). 157 Particle size distribution was evaluated by measuring a representative sub-sample of 100 APPs under a microscope. Metal analysis of the three APP types was carried out non-destructively using an energydispersive portable x-ray fluorescence (XRF) spectrometer (Niton XL3t He GOLDD+), with the focus on metals that are or have been commonly employed as biocides in antifouling paints $(\mathrm{Cu}, \mathrm{Hg}, \mathrm{Pb}, \mathrm{Sn}$ and $\mathrm{Zn})$. The instrument was operated in a low-density plastics mode with small-spot 3-mm collimation and thickness correction (between 0.5 and $3 \mathrm{~mm}$ ) and performance was verified by analysis of Niton plastic reference discs containing known concentrations of various metals. APP fragments were characterised in

\subsection{Experimental set-ups}

Two laboratory-based exposure experiments, an 18-day and 5-day exposure, were carried out for each species in a temperature-controlled facility $\left(13 \pm 1^{\circ} \mathrm{C}\right)$ under a $12: 12$ hour light:dark cycle. Estuarine sediment was collected from Saltram Park, where our samples revealed no evidence of APPs (MullerKaranassos et al., 2019); sediment was collected to a depth of approximately $20 \mathrm{~cm}$ at the same time as the biota, and sieved through a $1 \mathrm{~mm}$ stainless steel sieve with the aid of seawater to remove macrodebris.

172 Sediment was stored in a plastic tub covered with aluminium foil until experiments were carried out. Prior 173 to exposures, pre-weighed APPs were mixed into sediments in individual containers using a stainless-steel 174 spatula and then allowed to settle for $24 \mathrm{~h}$ prior to the introduction of animals. Owing to the high-density 175 of the APPs, we observed that particles remained within sediments during water changes. For the 18-day 176 exposure, APP concentrations were based on environmental concentrations identified at Hooe Lake (0$17718.8 \mathrm{~g} \mathrm{~L}^{-1}$; mean $4.2 \mathrm{~g} \mathrm{~L}^{-1}$ ) (Muller-Karanassos et al., 2019) adjusting for the density differences of the 178 different APPs (SI, Table S1). Trial experiments carried out using the maximum environmental APP 179 concentration $\left(18.8 \mathrm{~g} \mathrm{~L}^{-1}\right)$ led to mortality of all $\mathrm{H}$. diversicolor and $\mathrm{C}$. edule in the modern treatment within 1806 days and, therefore, the mean environmental APP concentration was used in order to assess sub-lethal 181 effects. Density-corrected APP concentrations were: $4.2 \mathrm{~g} \mathrm{~L}^{-1}$ for the historic biocidal treatment; $3.0 \mathrm{~g} \mathrm{~L}^{-1}$ 182 for the modern biocidal treatment; and $2.1 \mathrm{~g} \mathrm{~L}^{-1}$ for the non-biocidal silicone treatment. For the 5-day $\mathrm{LC}_{50}$ 
exposure, modern biocidal APPs (selected owing to their comparatively higher toxicity) were used at concentrations ranging from 0-30 $\mathrm{g} \mathrm{L}^{-1}$ (ragworms) and 0-6 $\mathrm{g} \mathrm{L}^{-1}$ (cockles).

After acclimation, individual organisms were weighed to ascertain pre-exposure wet weight. Ragworms were transferred into individual $100 \mathrm{~mL}$ polyethylene containers (1 ragworm per container) containing $50 \mathrm{~mL}$ of sieved sediment pre-mixed with APPs (silicone: $0.105 \mathrm{~g}$, historic: $0.209 \mathrm{~g}$, modern: $0.152 \mathrm{~g}$ ) or control sediment, and $50 \mathrm{~mL}$ of aerated FSW. Cockles were transferred into $1 \mathrm{~L}$ food-grade containers ( 1 cockle per vessel) containing $250 \mathrm{~mL}$ of control sediment or sediment pre-mixed with APPs (historic: $1.047 \mathrm{~g}$; modern: $0.759 \mathrm{~g}$; silicone: $0.525 \mathrm{~g}$ ) and $700 \mathrm{~mL}$ of well-aerated, natural seawater filtered through a $0.2 \mu \mathrm{m}$ glass fibre filter and diluted with ultrapure water to a salinity of 31.1 (matching estuarine conditions). Water was changed every 2-3 days and water quality parameters including temperature, $\mathrm{pH}$, salinity, conductivity and dissolved oxygen were measured using YSI Pro 1030 and Pro 20 meters at every water change (SI, Table S2). For the 18-day exposure, ragworms ( $\mathrm{n}=10$ per treatment) were each fed $8 \mathrm{~g}$ of hatched Artemia salina nauplii (Instant Baby Brine Shrimp, Ocean Nutrition) every other day (Moreira et al., 2005), and cockles ( $n=10$ per treatment) were fed every other day with an alternating diet of live Thalassiosira rotula (4000 cells $\mathrm{mL}^{-1}$ ) and freeze-dried multi-cell algal culture (5 Species Phytoplankton, Reefphyto). For the 5-day exposure, ragworms ( $n=5$ per APP concentration) and cockles ( $n=5$ per APP concentration) were not fed.

\subsection{8-day exposure}

\subsubsection{Feeding rate}

For ragworms, a feeding rate experiment was carried out following methods in Moreira et al. (2005). In summary, ragworms were transferred into individual Petri dishes containing $100 \mathrm{~A}$. salina nauplii and $20 \mathrm{~mL}$ of diluted seawater and allowed to feed in darkness for 1 hour. Remaining $A$. salina nauplii were counted and feeding rate was determined as the number of nauplii consumed per hour.

For cockles, clearance rate was assessed using an algal feeding assay. A known concentration of

T. rotula cells were introduced to experimental vessels and aliquots of water removed at the start of the experiment and after 1 hour. Five blank vessels were used to account for algal growth and settling. Algal concentration was assessed using the Sedgwick-Rafter counting method. Clearance rate $(C R)$ was calculated as described in Romano et al. (2011), as follows:

$$
C R=V \times \frac{\log C_{1}-\log C_{2}}{t} \times n
$$


213 where $V$ is the volume of water in the experimental vessel, $C_{1}$ is the initial algal concentration, $C_{2}$ is the

214 final algal concentration, $t$ is experimental duration, and $n$ is the number of cockles per vessel.

\section{$215 \quad$ 2.4.2 Weight change}

Animals were re-weighed (post-exposure wet weight) and weight change was determined as the

217 difference between pre- and post-exposure wet weight.

\subsubsection{Burrowing}

For ragworms, burrowing behaviour was analysed following methods by Buffet et al. (2011). Ragworms were placed in $100 \mathrm{~mL}$ containers with $50 \mathrm{~mL}$ clean estuarine sediment from Saltram Park and $50 \mathrm{~mL}$ of aerated filtered seawater. Burial state was recorded every 2 minutes for a total of 30 minutes.

For cockles, burrowing was analysed as in Byrne and O'halloran (2000) and Møhlenberg and Kiørboe (1983). Cockles were placed in individual containers set up in experimental chambers containing clean estuarine sediments, and burrowing state was recorded after $5,10,15,20,30,40,50,60,80,100$, 120 and 180 minutes. Cockles were judged to be burrowed when approximately $50 \%$ of the shell was covered by sediment.

\subsubsection{Metallothionein-like protein assay}

Metallothionein-like protein (MTLP) concentration in whole tissue was quantified for both species using the method described by Viarengo et al. (1997) and UNEP (1999) with a few alterations. Using frozen specimens, soft tissues were pooled in Petri dishes for each treatment (control, silicone, historic, modern) and defrosted in an oven for 10 minutes at $50^{\circ} \mathrm{C}$. Samples were weighed and volume of tissue measured before homogenisation of tissue in 2 volumes of homogenising buffer containing $\beta$-mercaptoenthanol, phenylmethylsuphonylfuride and leupeptin. Homogenisation was performed using a $600 \mathrm{~W}$ Morphy Richards 402058 hand-blender in beakers until tissue was smooth enough to be removed using a $1 \mathrm{~mL}$ Gilson pipette. Two $\mathrm{mL}$ of sample was pipetted into $2 \mathrm{~mL}$ centrifuge tubes (6 replicates per treatment) and centrifuged at $2{ }^{\circ} \mathrm{C}, 14,000 \times \mathrm{g}$ for 45 minutes. One $\mathrm{mL}$ of supernatant was carefully removed by pipette and added to $1.05 \mathrm{~mL}$ of cold $\left(-20^{\circ} \mathrm{C}\right)$ absolute ethanol and $80 \mu \mathrm{L}$ of chloroform in $2 \mathrm{~mL}$ centrifuge tubes stored on ice. Tubes were inverted and vortexed before centrifugation at $0{ }^{\circ} \mathrm{C}$ and $6000 \mathrm{xg}$ for 10 minutes. Supernatant was carefully pipetted off into $15 \mathrm{~mL}$ tubes and volume recorded for each sample.

240 Ten $\mu \mathrm{L}$ of a $100 \mathrm{mg} \mathrm{mL}^{-1}$ stock of RNA, $40 \mu \mathrm{L}$ of $37 \% \mathrm{HCl}$ and 3 volumes of cold absolute ethanol were 241 added before vortexing and storing at $-20^{\circ} \mathrm{C}$ for 1 hour. Samples were then centrifuged at $0{ }^{\circ} \mathrm{C}$ and 4000 $242 \mathrm{xg}$ for 15 minutes to form a pellet. Supernatant was carefully removed and the pellet washed with $5 \mathrm{~mL}$ 243 of a cleaner solution (87:1:12 ethanol/chloroform/homogenising buffer, stored at $\left.-20^{\circ} \mathrm{C}\right)$. Samples were 244 re-centrifuged at $0{ }^{\circ} \mathrm{C}$ and $4000 \times \mathrm{g}$ for 5 minutes before removal of supernatant and drying. $150 \mu \mathrm{L}$ of 
$2450.25 \mathrm{M} \mathrm{NaCl}$ solution and $150 \mu \mathrm{L}$ of $1 \mathrm{~N} \mathrm{HCl}$ containing $4 \mathrm{mM}$ EDTA were added and then vortexed.

246 Standards were made up using a $1 \mathrm{mg} \mathrm{mL}^{-1}$ solution of glutathione in $0.25 \mathrm{M} \mathrm{NaCl}$, and blanks were made 247 up with $150 \mu \mathrm{L}$ of $0.25 \mathrm{M} \mathrm{NaCl}$ solution and $150 \mu \mathrm{L}$ of $1 \mathrm{~N} \mathrm{HCl}$ containing $4 \mathrm{mM}$ EDTA. Just before analysis,

$2480.43 \mathrm{mM}(7.14 \mathrm{mg} / 42 \mathrm{~mL}$ ) DTNB (Ellman's reagent) was dissolved in $0.2 \mathrm{M}$ phosphate buffer pH 8 249 containing $2 \mathrm{M} \mathrm{NaCl}$ and $4.2 \mathrm{~mL}$ of this solution was added to all samples, standards and blanks. All tubes 250 were then centrifuged at 3,000 xg for 5 minutes at room temperature. Absorbance was measured at 412 $251 \mathrm{~nm}$ in a VWR UV-3100 PC spectrophotometer.

\subsection{5-day exposure}

\section{$254 \quad 2.5 .1 L_{50}$ and $E C_{50}$}

Daily checks were carried out for mortality of both species. Healthy ragworms will naturally burrow to avoid predation (Kalman et al., 2009) and have a fast reaction time (personal observations).

257 Ragworms were recorded as dead when they appeared to be motionless at the surface of the sediment 258 and there was no response to touch, and adversely affected when they were found on the sediment 259 surface and only reacted slightly to touch. Cockles were also deemed to be dead when no response was 260 observed on gentle touching of valves or foot, and adversely affected when exhibiting gaping behaviour 261 with minimal response to touch (Thompson and Richardson, 1993).

\subsection{Statistical analysis}

All ragworm and cockle data were checked for normality using Shapiro-Wilk's test. For the nonparametric ragworm data a Kruskal-Wallis test followed by Wilcoxon Rank Sum test was used, while a one-way analysis of variance (ANOVA) with Tukey's post-hoc test was used to compare differences in parametric cockle data. A generalised linear model (GLM) with binomial distribution was used to compare the number of animals burrowed after 30 minutes across treatments. The 5 -day $\mathrm{LC}_{50}$ and $\mathrm{EC}_{50}$ values were calculated by probit analysis in SPSS. All other analyses were carried out using R statistical software v3.5.1

$270(\underline{R}, 2019)$. Biological data is presented as mean values \pm standard error, while metal chemistry data is 271 presented as mean values \pm standard deviation; significant difference is attributed where $p<0.05$.

\section{3. Results}

\section{$274 \quad 3.1$ APP characterisation}


APPs ranged from $0.0625-1 \mathrm{~mm}$ in size, with particle size varying between the three APP types

276 (Figure 3). Overall, historic biocidal APPs had the highest proportion of particles in the size range 0.125-

$2770.25 \mathrm{~mm}$ (37.6\%), modern biocidal APPs had the smallest particle size, with $43.6 \%$ of particles in the size 278 range $0.0625-0.125 \mathrm{~mm}$. Non-biocidal silicone antifouling paint had a "rubber-like" consistency and was 279 much harder to breakdown into smaller particles via cryogenic grinding, and as a result these APPs had 280 the largest particle size, with $39.7 \%$ of particles in the size range $0.5-1 \mathrm{~mm}$. Metal concentrations varied considerably between APP types (Table 1). Historic biocidal APPs had the highest concentrations of $\mathrm{Zn}, \mathrm{Pb}$ and $\mathrm{Hg}$, and relatively high $\mathrm{Cu}$ concentrations, whereas modern biocidal APPs had the highest Cu concentrations with much lower concentrations of Zn. Copper was

284 detected in one reading taken from the non-biocidal silicone APPs but Zn was not detected; however, 285 there were detectable concentrations of $\mathrm{Sn}$ and $\mathrm{Hg}$ in the these APPs.

286

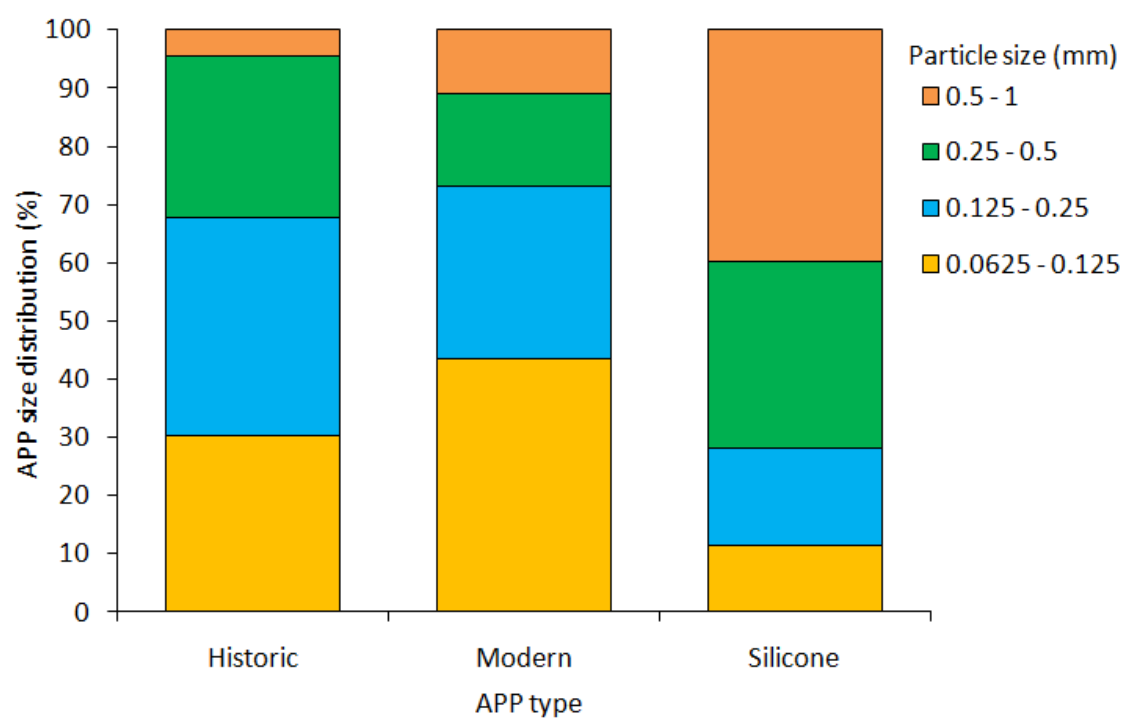

288 Figure 3. Particle size distribution of the different types of APPs used in exposure experiments.

290 Table 1. Metal concentrations $\left(\mathrm{mg} \mathrm{kg}^{-1}\right)$ in APPs used in 18-day and 5-day assays. The mean of 5 291 measurements is shown for each APP type \pm standard error. Metal concentrations not detected were 292 replaced with measurement detection limits (values where $<$ is shown) for the calculation of means.

\begin{tabular}{llllll}
\hline APP type & Cu & Zn & Sn & Pb & Hg \\
\hline Historic & 148000 & 69000 & 412 & 1030 & 1620 \\
& 142000 & 64500 & 408 & 2010 & 1350 \\
& 176000 & 73200 & 326 & 565 & 1930
\end{tabular}




\begin{tabular}{|c|c|c|c|c|c|}
\hline & 181000 & 87100 & 576 & 503 & 2570 \\
\hline & 168000 & 78200 & 510 & 1210 & 1590 \\
\hline Mean & $163000 \pm 769$ & $74400 \pm 3901$ & $446 \pm 44$ & $1060 \pm 272$ & $1810 \pm 211$ \\
\hline \multirow[t]{5}{*}{ Modern } & 440000 & 4900 & 977 & 401 & 399 \\
\hline & 427000 & 9180 & 853 & $<237$ & 394 \\
\hline & 428000 & 18000 & 941 & $<225$ & 459 \\
\hline & 420000 & 17200 & 782 & $<246$ & 436 \\
\hline & 421000 & 13500 & 750 & $<254$ & 411 \\
\hline Mean & $427000 \pm 357$ & $12600 \pm 247$ & $861 \pm 44$ & $272 \pm 32$ & $420 \pm 12$ \\
\hline \multirow[t]{5}{*}{ Silicone } & $<126$ & $<81$ & 838 & $<24$ & 69 \\
\hline & $<140$ & $<89$ & 913 & $<30$ & 77 \\
\hline & 150 & $<99$ & 863 & $<42$ & 69 \\
\hline & $<130$ & $<86$ & 705 & $<38$ & 74 \\
\hline & $<145$ & $<94$ & 702 & $<34$ & 78 \\
\hline Mean & $138 \pm 4$ & $<90 \pm 3$ & $804 \pm 43$ & $34 \pm 3$ & $73 \pm 2$ \\
\hline
\end{tabular}

\subsection{8-day assay}

Individual ragworms ( $H$. diversicolor) were used for testing sub-lethal end-points across four treatments (control $n=9$, non-biocidal silicone $n=8$, historic biocidal $n=9$ and modern biocidal $n=10$ ). Three ragworms, from the control, non-biocidal silicone and historic biocidal treatments, spawned during the exposure and were removed from further analysis to avoid bias. One ragworm from the non-biocidal silicone treatment was lost during processing before end-point experiments were carried out. For cockles (C. edule), $100 \%$ mortality was observed for the modern biocidal treatment after 10 days, so sub-lethal endpoints could not be assessed; all cockles survived in control, non-biocidal silicone and historic biocidal treatments $(n=10)$.

\subsubsection{Feeding rate}

The highest feeding rate occurred in the control treatment $\left(17 \pm 4\right.$ nauplii $\mathrm{h}^{-1}$ ind $\left.^{-1}\right)$ and the lowest was observed in the modern biocidal treatment $\left(6 \pm 2\right.$ nauplii $\mathrm{h}^{-1}$ ind. $\left.{ }^{-1}\right)$. The feeding rate of ragworms differed significantly between treatments (One-way ANOVA: $F_{3,32}=3.131, p<0.05$; Figure 4A), and the posthoc test showed a significant difference between the modern biocidal treatment and control (Tukey: $308 p<0.05)$. 
No significant difference in clearance rates of cockles between treatments was observed (control: $0.60 \mathrm{~L} \mathrm{~h}^{-1}$ ind. ${ }^{-1}$; non-biocidal silicone: $0.63 \mathrm{~L} \mathrm{~h}^{-1}$ ind.$^{-1}$; historic biocidal: $0.82 \mathrm{~L} \mathrm{~h}^{-1}$ ind. ${ }^{-1}$; ANOVA: $F_{2,27}=2.797$, $311 p=0.08$; Figure 4B).

\subsubsection{Weight change}

Ragworms showed a significant difference in mean weight change between treatments (KruskalWallis: $p<0.01$; Figure 4C). Exposure to biocidal APPs resulted in a marked decrease in weight, however when compared with controls, significant differences were only observed in ragworms exposed to modern biocidal APPs (18.5 $\pm 4 \%$ weight loss; Wilcoxon: $p<0.01)$.

Weight change in cockles was not significantly affected by treatment (One-way ANOVA: $F_{2,27}=3.30$,

$318 p=0.052$; Figure 4D). However, compared with controls, cockles exposed to non-biocidal silicone APPs did 319 show a significantly greater weight loss (Tukey: $p<0.05$ ).

\subsubsection{Burrowing}

An average of $60 \pm 16 \%$ of ragworms exposed to modern biocidal APPs had buried after 30 minutes, while an average of $88-100 \%$ of individuals in the other treatments had successfully buried in this time period. However, there were no significant differences between treatments (GLM: $p>0.05$; Figure 4E). Approximately two-thirds of cockles had successfully buried after 180 minutes across all treatments, with no significant difference between treatments (GLM: $p>0.05$; Figure 4F).

\subsubsection{Metallothionein-like protein}

MTLP concentrations in ragworms averaged $59 \mu \mathrm{g} \mathrm{g}^{-1}$ in controls, with no significant difference between treatments (Kruskal-Wallis: $p=0.07$ ); however, ragworms exposed to the historic biocidal APPs $p<0.05$; Figure 4G).

Whole-tissue MTLP concentrations in cockles averaged $20.6 \mu \mathrm{g} \mathrm{g}^{-1}$ in controls, which is comparable with other studies (Aly et al., 2014). MTLP concentrations were significantly affected by

334 historic biocidal (26.2 $\mathrm{gg} \mathrm{g}^{-1}$; Tukey: $\left.p<0.05\right)$ and modern biocidal (31.1 $\mathrm{gg} \mathrm{g}^{-1}$; Tukey: $\left.p<0.01\right)$ treatments, 335 as compared with controls. 
Harbour ragworm

Hediste diversicolor

(A)

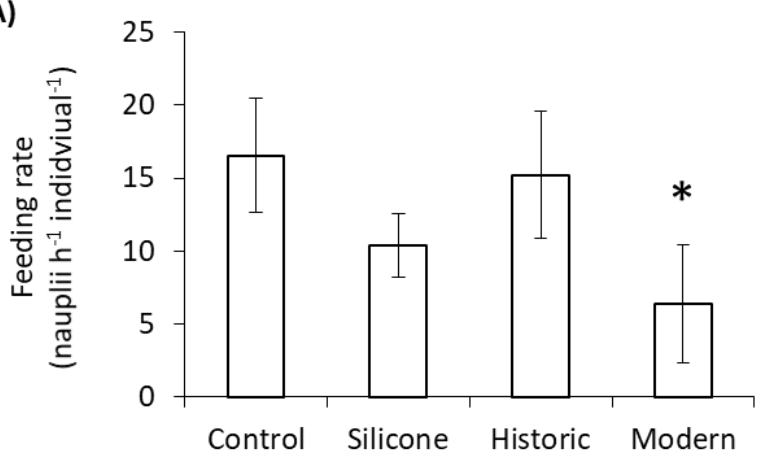

(C)
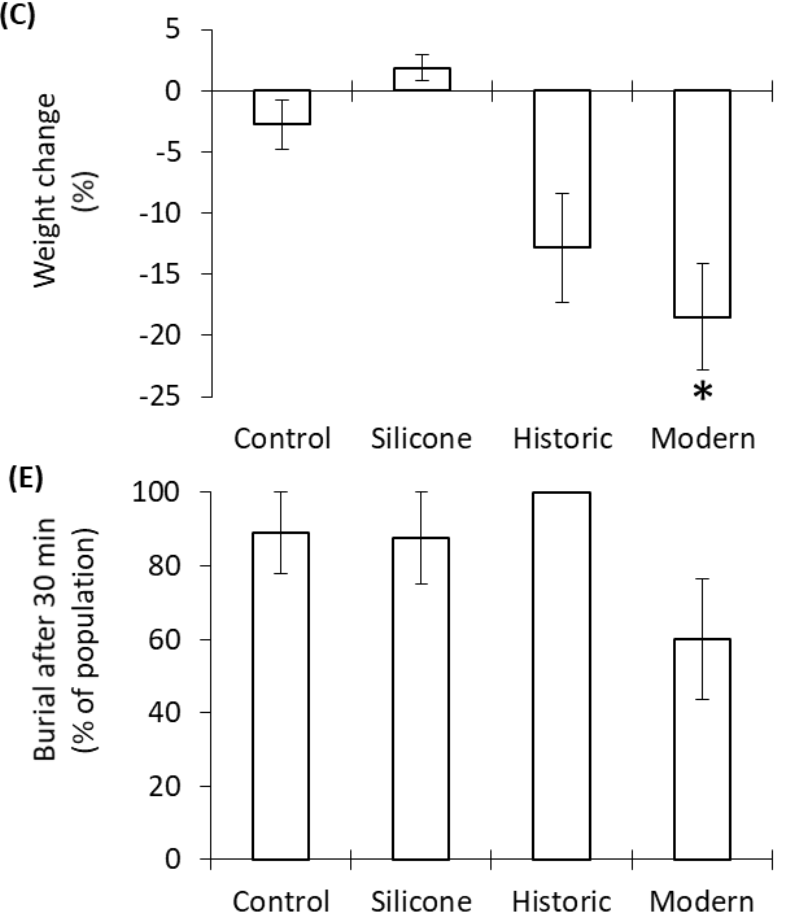

(G)

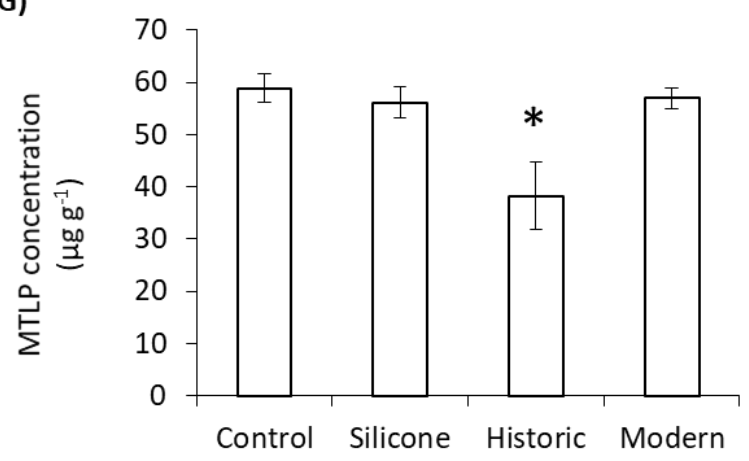

Edible cockle

Cerastoderma edule

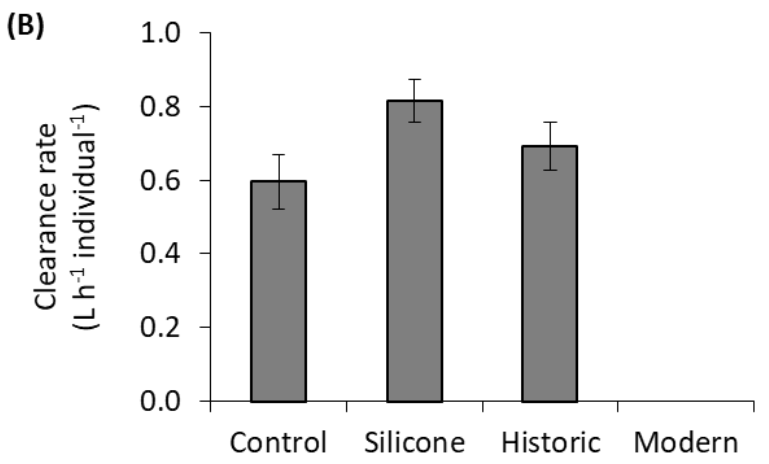

(D)
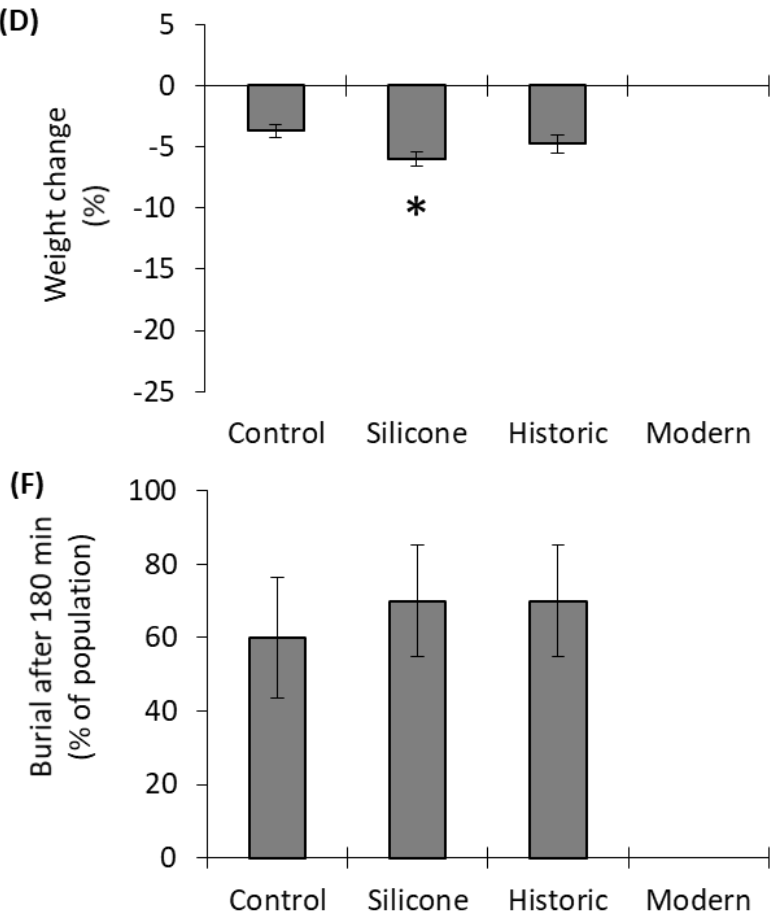

(H)

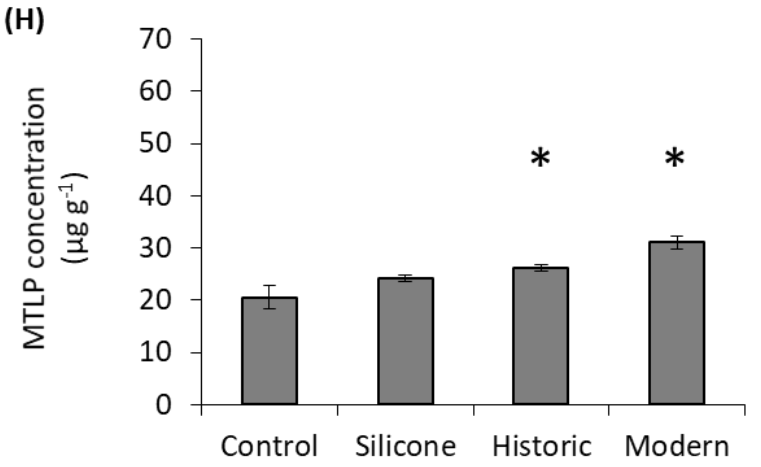

Figure 4. Sub-lethal health responses in ragworms (white bars) and cockles (grey bars) following an 18day exposure to controls and silicone, historic or modern APP treatments: (A) Feeding rates (nauplii individual ${ }^{-1}$ hour $\left.^{-1}\right)$; (B) Clearance rates $\left(\mathrm{L} \mathrm{h}^{-1}\right.$ individual $\left.^{-1}\right)$; (C-D) Weight change (\%); (E-F) Percentage of 
341 individuals burrowed after 30 minutes (ragworm) and 180 minutes (cockles); (G-H) Metallothionein-like

342 protein (MTLP) concentration, noting that cockles in modern treatment died before the end of the 18-day 343 exposure period. * denotes significant difference from control treatment. Error bars indicate standard 344 error.

\subsection{5-day assay: LC50s}

The 5-day $\mathrm{LC}_{50}$ was 19.9 APP g L-1 for ragworms (Figure 5A) and $2.3 \mathrm{~g} \mathrm{~L}^{-1}$ for cockles (Figure 5B). In 348 the control treatment, there were no mortalities for either species. The 5-day $\mathrm{EC}_{50}$ values were calculated 349 as $14.6 \mathrm{~g} \mathrm{~L}^{-1}$ for ragworms and $1.4 \mathrm{~g} \mathrm{~L}^{-1}$ for cockles (data not shown).

(A)

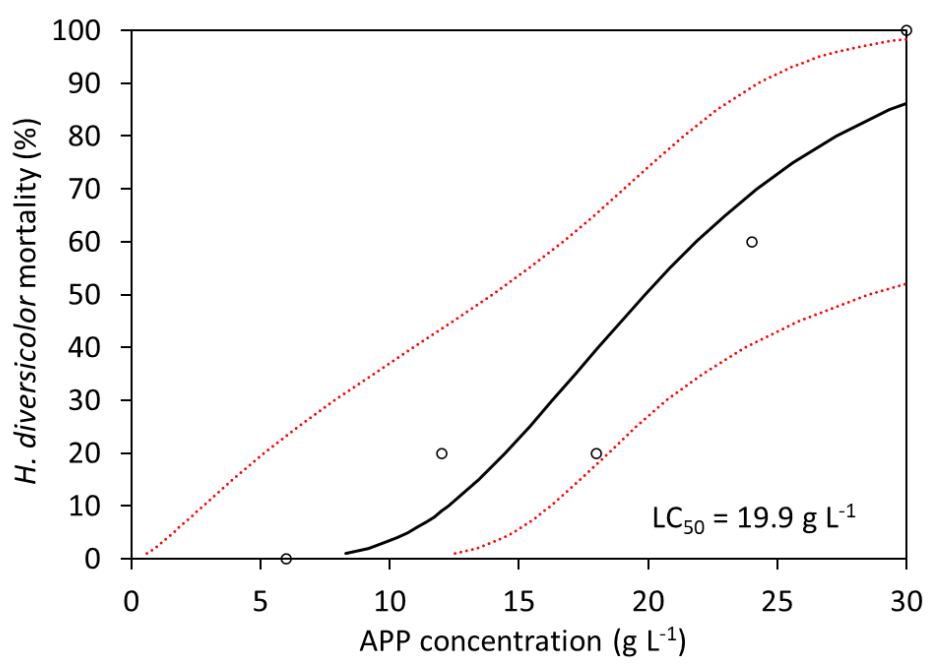

(B)

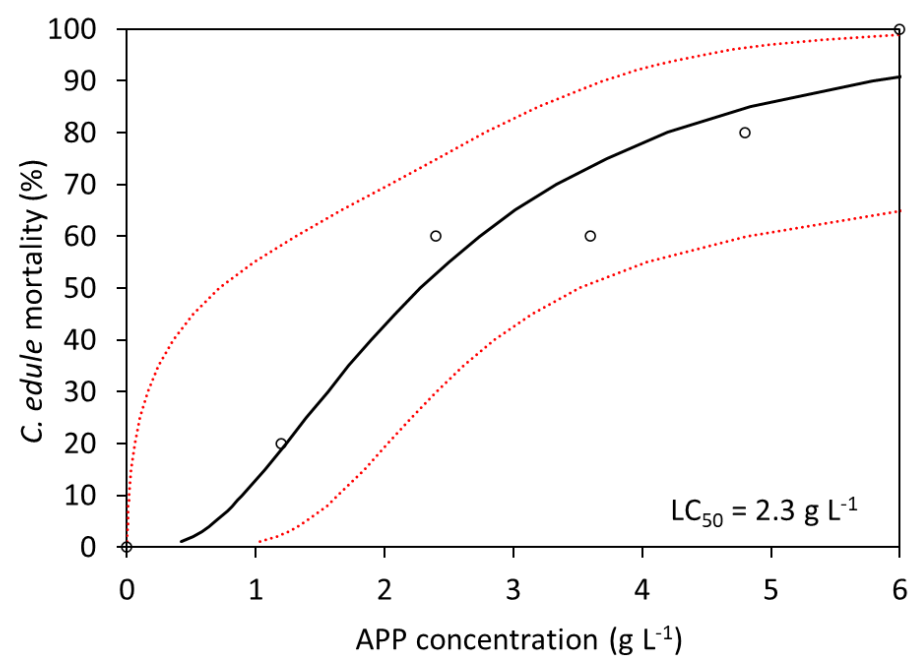

APP concentration $\left(\mathrm{g} \mathrm{L}^{-1}\right)$

352 Figure 5. 5-day median lethal concentration ( $\left(\mathrm{CC}_{50}\right)$ dose-response curves (black line) with $95 \%$ confidence 353 intervals (orange lines) for (A) ragworms and B) cockles exposed to modern APPs. 


\section{Discussion}

\subsection{8-day exposure}

Results from the 18-day study demonstrate that exposure to modern biocidal APPs at environmentally relevant concentrations leads to adverse health effects in the ragworm $\mathrm{H}$. diversicolor and mortality in the cockle $C$. edule. As compared with controls, significant net decreases in weight $(15.7 \pm 5 \%)$ and feeding rate $(10.2 \pm 4 \%)$ were observed in ragworms exposed to modern biocidal APPs; furthermore modern biocidal APPs were associated with the highest percentage of un-burrowed ragworms, with $29 \pm 20 \%$ fewer ragworms burrowed after 30 minutes compared to the average control, although this difference was not statistically significant. Modern biocidal APPs were acutely toxic to cockles, resulting in mortality of all replicates in the first 10 days of exposure. Both historic and modern biocidal APPs caused significant increases in MTLPs in cockles. Largely, historic biocidal and non-biocidal silicone APPs did not cause substantial sub-lethal health effects in ragworms or cockles, although it was observed that exposure to historic biocidal APPs led to substantial weight loss in the ragworms.

A reduction in weight, feeding and burrowing activity of ragworms could lead to a range of consequences in the natural environment. Impairment of feeding activity in marine organisms can directly affect population parameters such as growth, reproduction (Maltby et al., 2001) and energy intake (Kalman et al., 2009). Previous studies have demonstrated that Cu exposure can have lethal and sub-lethal effects on ragworms, including reduced burrowing activity (Thit et al., 2015) and feeding (Moreira et al., 2005). Reduced burrowing efficiency in ragworms and cockles increases the likelihood of predation (Kalman et al., 2009), and reduces bioturbation activity - a vital process for sediment processing and deposition of organic matter in estuarine ecosystems (Moreira et al., 2006). Increased mortality of cockles caused by exposure to APPs could lead to a decrease in natural populations, with implications for ecosystem functionality (e.g. bioturbation and food webs). Soroldini et al. (Soroldoni et al., 2017; Soroldoni et al., 2020) similarly found an increase in mortality in copepods and benthic invertebrates with increasing concentrations of APPs originating from a commonly-used contemporary commercial antifouling paint containing high concentrations of $\mathrm{Cu}$ and $\mathrm{Zn} \mathrm{(Cu:} 234 \pm 0.27 \mathrm{~g} \mathrm{~kg}^{-1}, \mathrm{Zn}: 112 \pm 0.84 \mathrm{~g} \mathrm{~kg}^{-1}$, $\left.\mathrm{Pb}: 0.51 \pm 0.01 \mathrm{~g} \mathrm{~kg}^{-1}\right)$. Another study found that leachate from sediment contaminated 1 with APPs caused a reduction in gram-negative bacteria (Vibrio fischeri) bioluminescence, decreased growth rate of the red algae (Ceramium tenuicorne) and reduced larval development in the harpacticoid copepod Nitocra 
spinipes (Ytreberg et al., 2010); while Cu was found to be more toxic to $V$. fischeri and C. tenuicorne, $N$. spinipes was more sensitive to $\mathrm{Zn}$ (Ytreberg et al., 2010).

In comparing the metal profiles of the biocidal APPs, it was evident that the modern paints contained far higher copper concentrations (Cu: modern: 427,000 \pm 7,000 mg kg-1; historic: 163,000 \pm $15,600 \mathrm{mg} \mathrm{kg}^{-1}$ ). The lower $\mathrm{Cu}$ concentrations in the historic biocidal APPs could be attributed to the weathering of historic APP and a longer period of Cu leaching from aged historic paints (Rees et al., 2014), leading to more inert APPs and therefore a reduced toxicity. However, historic APPs contained the highest Zn concentrations $\left(74,400 \pm 7,800 \mathrm{mg} \mathrm{kg}^{-1}\right)$ and also contain other toxic metals such as $\mathrm{Pb}(1,060 \pm 543 \mathrm{mg}$ $\left.\mathrm{kg}^{-1}\right), \mathrm{Hg}\left(1,810 \pm 423 \mathrm{mg} \mathrm{kg}^{-1}\right)$ and $\mathrm{Sn}\left(446 \pm 87 \mathrm{mg} \mathrm{kg}^{-1}\right)$, which may still pose an ongoing risk to non-target organisms. Based on the heightened mortality and sub-lethal effects stemming from modern biocidal APP exposure, we surmise $\mathrm{Cu}$ is the most toxic biocidal metal present. Soroldoni et al. (2017) similarly identified that Cu was more toxic to copepods than $\mathrm{Zn}$. Once metals have been taken up by an organism, they can be detoxified by accumulation in metal-rich granules or by binding with metallothionein (MT) and MTLP that regulate metal concentrations (Rainbow, 2007). The elevated MTLP in cockles from historic and modern biocidal treatments compared to the control suggests an upregulation of MTLP in response to metal exposure, particularly in the modern biocidal treatment (despite these cockles not surviving the full 18-day exposure). MTLP concentrations in ragworms were not affected by treatment. Previous studies also found no relationship between accumulated metal concentrations and MTLP levels in ragworms (Poirier et al., 2006; Solé et al., 2009), and several studies have shown that exposure to Cu leads to an accumulation of this metal in H. diversicolor (Berthet et al., 2003; Geffard et al., 2005). While ragworms have an intolerance to $\mathrm{Cu}$, they have shown the capacity to regulate $\mathrm{Zn}$ body concentrations, thought to occur by reduced metal uptake rates, increased excretion rates and/or through storage of metals in granules or MTLPs (Berthet et al., 2003; Geffard et al., 2005).

Other compounds found in antifouling paint such as booster biocides, solvents and binders can also have toxic effects (Karlsson et al., 2010) and the mixture of metals and other compounds found in APPs are likely to have synergistic effects (Soroldoni et al., 2017). It is therefore important to examine the toxicity of APPs as a whole, in addition to that of individual compounds found within antifouling paints. APPs were not tested for other compounds in this study, although they are likely to have contributed to the high toxicity observed with modern biocidal APPs. Although uptake routes were not investigated in the current study, exposure to biocides likely occurred via ingestion of APPs and uptake of dissolved metals leached into the water column and sediment porewater. By design, biocidal antifouling paints will constantly release metal ions into the surrounding water to prevent adherence and growth of fouling 
organisms, so it is expected that biocidal APPs will continue to emit Cu and Zn throughout their lifespan,

418 although whether the rate of dissipation changes over time remains unclear. A number of studies have

419 exposed marine organisms to APP leachate solutions, which have been routinely demonstrated to be

420 readily taken up by biota and cause toxicity (Gammon et al., 2009; Katranitsas et al., 2003; $\underline{\text { Soroldoni et }}$

421 al., 2018b; Tolhurst et al., 2007). In the Plym estuary, the smallest APPs observed were $\sim 0.5 \mathrm{~mm}$ in size

422 (Muller-Karanassos et al., 2019); detecting smaller particles was hindered by sampling and analytical

423 limitations, however abiotic and biotic processes can be expected to contribute to the proliferation of

424 even smaller APPs. In this study APPs were prepared to $0.0625-1 \mathrm{~mm}$ in size, with differences in particle

425 size profiles of biocidal and non-biocidal APPs observed: the majority of the "rubber-like" silicone APPs

426 being $>0.5 \mathrm{~mm}$, and the majority of biocidal APPs being $<0.5 \mathrm{~mm}$ diameter. We cannot say for certain

427 whether the observed differences in particle size profiles might influence toxicity, however we consider

428 all particles to be in the normal prey size range of cockles and ragworms. Toxicity studies using plastic

429 particulates of distinct size (i.e. nano- vs micro) have revealed size dependent effects, with differences

430 stemming from different modes of biological action; for example, $50 \mathrm{~nm}$ polystyrene nanoplastics

431 triggered an immune response in mussels (likely owing to their capacity to readily translocate into

432 circulatory fluids) while exposure to $20 \mu \mathrm{m}$ polystyrene microplastics caused no observable impact (Cole

433 et al., 2020). It is interesting to consider whether exposure to APPs of markedly different particle size (i.e.

434 nano vs micro) would significantly effect toxicity; for example, might smaller APPs with larger surface

435 areas increase metal leaching or penetrate deeper into tissues causing cellular toxicity (Jeong et al., 2016)?

436 Further work is needed to clarify the mechanisms responsible for toxicity of APPs to benthic organisms

437 observed in the present study.

438 Non-biocidal silicone paints, absent of $\mathrm{Cu}$ and $\mathrm{Zn}$, caused no adverse health effects on cockles or

439 ragworms, supporting our hypothesis that $\mathrm{Cu}$, likely in combination with other compounds, is the most

440 toxic component of APPs. This is further supported by other studies: for example, Watermann et al. (2005)

441 found that silicone coatings did not negatively affect barnacle cypris larvae settlement and luminescence

442 of the bacteria V. fischeri; and Karlsson and Eklund (2004) observed no changes to growth of two

443 macroalgae (C. tenuicorne and Ceramium strictum) and no mortality of the copepod $N$. spinipes when

444 exposed to silicone paint. Biocide-free silicone coatings may be a suitable alternative to modern biocidal

445 antifouling paints for high speed vessels, but further studies are needed to assess long-term effects.

446 Owing to their alkyd-resin base, APPs can be considered as microplastics (Hartmann et al., 2019).

447 Microplastic debris can be ingested by a wide array of marine organisms, with evidence of sub-lethal harm

448 in a number of studies e.g. Cole et al. (2015), Wright et al. (2013). In this study, it is evident that non- 
biocidal silicone APPs (absent of metal additives) have a far lower toxicity than APPs containing biocides,

450 highlighting the importance of considering additive and metal profiles when evaluating microplastic 451 toxicity. While the physical properties of a microplastic (e.g. size, shape) have been shown to interfere 452 with feeding and movement in marine biota (see Galloway et al. (2017) and Setälä et al. (2018)); , their 453 chemical composition is often overlooked. However, microplastics more generally should not be 454 considered as a single polymeric compound, but a mixture of polymers, containing monomers and 455 additives including metals, emollients, phthalates and flame retardants (Rochman et al., 2019). These additives can be highly toxic and have been associated with sub-lethal health effects and endocrine disruption in marine invertebrates (Browne et al., 2013; Cole et al., 2019).

\subsection{5-day assay}

Cockles were found to be much more sensitive to modern biocidal APPs when compared to ragworms. The $\mathrm{LC}_{50}$ and $\mathrm{EC}_{50}$ for cockles $\left(2.3 \mathrm{~g} \mathrm{~L}^{-1}\right.$ and $1.4 \mathrm{~g} \mathrm{~L}^{-1}$ respectively) were almost an order of magnitude lower than for ragworms (19.9 $\mathrm{g} \mathrm{L}^{-1}$ and $14.6 \mathrm{~g} \mathrm{~L}^{-1}$ respectively). The maximum concentration of APPs found within the Plym Estuary at Hooe Lake (Muller-Karanassos et al., 2019), where boating activity is significant, was $18.8 \mathrm{~g} \mathrm{~L}^{-1}$, which is well above the $\mathrm{LC}_{50}$ and $\mathrm{EC}_{50}$ for cockles and above the $\mathrm{EC}_{50}$ for ragworms. This suggests that APP concentrations found in the natural environment have the potential to cause mortality to cockles and adverse effects in ragworms.

Studies have shown that ragworms and cockles originating from metal-contaminated sites may have a higher tolerance to $\mathrm{Cu}$ and $\mathrm{Zn}$ compared to uncontaminated sites (Durou et al., 2005; Mouneyrac et al., 2003; Naylor, 1987). It is therefore not possible to generalise the findings of this study for all ragworm and cockle populations since the $\mathrm{LC}_{50}$ for APPs will likely differ between sites. Indeed, ragworm and cockles could be identified in the vicinity of Hooe Lake, albeit in sparser numbers than elsewhere (personal observations). Metal tolerance has also been found to differ between taxa and more sensitive benthic organisms are expected to have lower APP LC $_{50}$ values. A study by Buffet et al. (2011) found that the bivalve mollusc Scrobicularia plana was less tolerant to Cu nanoparticles compared to $H$. diversicolor, supporting the findings of the current study.found a 4-day $L_{50}$ value of $0.14 \%$ of APPs by mass of dry sediment for the epibenthic copepod Nitokra sp. The current study showed a similar 5 -day $\mathrm{LC}_{50}(0.15 \%$ of APPs by mass of wet sediment) for $C$. edule and a much higher 5 -day LC $_{50}$ ( $1.42 \%$ of APPs by mass of wet sediment) for $H$. diversicolor. These values are not directly comparable since the exposure periods differ and sediment wet weight was used instead of dry weight. However, it can be assumed that if water were removed from sediment in the current study this would produce higher percentages of APPs by mass of 
dry sediment. This suggests that cockles are more tolerant than copepod species to APP-contaminated sediments, likely due to their larger body size and ability to accumulate metals.

\section{Conclusions}

Given the current evidence, it can be concluded that biocidal APPs present a source of contaminant metals to estuarine and coastal sediments. Exposure to these anthropogenic particles pose both a physical and toxic risk to benthic species and the wider food web, necessitating stricter regulations for antifouling waste in marinas and boatyards. APPs derived from copper-based biocidal paints proved most toxic to cockles and ragworms. While exposure to silicone-based non-biocidal APPs resulted in increased weight-loss in cockles, current evidence indicates non-biocidal antifouling paints to be less toxic to non-target organisms.

\section{Acknowledgements}

494 The study was funded by a Royal Society standard grant (RSG\R1\180048).

\section{References}

Almeida, E., Diamantino, T.C., de Sousa, O., 2007. Marine paints: The particular case of antifouling paints. Progress in Organic Coatings 59, 2-20. Aly, W., Williams, I.D., Hudson, M.D., 2014. Limitations of metallothioneins in common cockles (Cerastoderma edule) and sponges (Haliclona oculata) as biomarkers of metal contamination in a semi-enclosed coastal area. Science of the Total Environment 473-474, 391-397.

Berthet, B., Mouneyrac, C., Amiard, J.C., Amiard-Triquet, C., Berthelot, Y., Le Hen, A., Mastain, O., Rainbow, P.S., Smith, B.D., 2003. Accumulation and soluble binding of cadmium, copper, and zinc in the polychaete Hediste diversicolor from coastal sites with different trace metal bioavailabilities. Archives of Environmental Contamination and Toxicology 45, 468. Boucher, J., Friot, D., 2017. Primary Microplastics in the Oceans: A Global Evaluation of Sources. IUCN, Gland, Switzerland, p. 43. Browne, M.A., Niven, S.J., Galloway, T.S., Rowland, S.J., Thompson, R.C., 2013. Microplastic moves pollutants and additives to worms, reducing functions linked to health and biodiversity. Current Biology 23, 2388-2392.

Budd, G.C., 2008. Hediste diversicolor Ragworm, in: Tyler-Walters, H., Hiscock, K. (Eds.), Marine Life Information Network: Biology and Sensitivity Key Information Reviews. Marine Biological Association, Plymouth.

Buffet, P.-E., Tankoua, O.F., Pan, J.-F., Berhanu, D., Herrenknecht, C., Poirier, L., AmiardTriquet, C., Amiard, J.-C., Bérard, J.-B., Risso, C., Guibbolini, M., Roméo, M., Reip, P., ValsamiJones, E., Mouneyrac, C., 2011. Behavioural and biochemical responses of two marine invertebrates Scrobicularia plana and Hediste diversicolor to copper oxide nanoparticles. Chemosphere 84, 166-174. 
Byrne, P.A., O'halloran, J., 2000. Acute and sublethal toxicity of estuarine sediments to the

Chambers, L.D., Stokes, K.R., Walsh, F.C., Wood, R.J.K., 2006. Modern approaches to marine antifouling coatings. Surface \& Coatings Technology 201, 3642-3652.

Cole, M., Coppock, R., Lindeque, P.K., Altin, D., Reed, S., Pond, D.W., Sørensen, L., Galloway, T.S., Booth, A.M., 2019. Effects of Nylon Microplastic on Feeding, Lipid Accumulation, and Moulting in a Coldwater Copepod. Environmental Science \& Technology.

Cole, M., Liddle, C., Consolandi, G., Drago, C., Hird, C., Lindeque, P.K., Galloway, T.S., 2020. Microplastics, microfibres and nanoplastics cause variable sub-lethal responses in mussels (Mytilus spp.). Marine pollution bulletin 160, 111552.

Cole, M., Lindeque, P., Fileman, E., Halsband, C., Galloway, T.S., 2015. The impact of polystyrene microplastics on feeding, function and fecundity in the marine copepod Calanus helgolandicus. Environmental Science \& Technology 49, 1130.

Connelly, D.P., Readman, J.W., Knap, A.H., Davies, J., 2001. Contamination of the Coastal Waters of Bermuda by Organotins and the Triazine Herbicide Irgarol 1051. Marine Pollution Bulletin 42, 409-414.

Durou, C., Mouneyrac, C., Amiard-Triquet, C., 2005. Tolerance to metals and assessment of energy reserves in the polychaete Nereis diversicolor in clean and contaminated estuaries. Environmental Toxicology 20, 23-31.

Eklund, B., Johansson, L., Ytreberg, E., 2014. Contamination of a boatyard for maintenance of pleasure boats. Journal of Soils and Sediments 14, 955-967.

Evans, S.M., Leksono, T., McKinnell, P.D., 1995. Tributyltin pollution: A diminishing problem following legislation limiting the use of TBT-based anti-fouling paints. Marine Pollution Bulletin 30, 14-21.

Galloway, T.S., Cole, M., Lewis, C., 2017. Interactions of microplastic debris throughout the marine ecosystem. Nature Ecology \& Evolution 1, s41559-41017-40116. Gammon, M., Turner, A., Brown, M.T., 2009. Accumulation of $\mathrm{Cu}$ and $\mathrm{Zn}$ in discarded antifouling paint particles by the marine gastropod, Littorina littorea. Estuarine, Coastal and Shelf Science 84, 447-452.

Geffard, A., Smith, B., Amiard-Triquet, C., Jeantet, A., Rainbow, P., 2005. Kinetics of trace metal accumulation and excretion in the polychaete Nereis diversicolor. International Journal on Life in Oceans and Coastal Waters 147, 1291-1304.

Goss-Custard, J.D., Jones, R.E., Newbery, P.E., 1989. The Ecology of the Wash. I. Distribution and Diet of Wading Birds (Charadrii). Journal of Applied Ecology 14, 681-700.

Hartmann, N.B., Hüffer, T., Thompson, R.C., Hassellöv, M., Verschoor, A., Daugaard, A.E., Rist, S., Karlsson, T., Brennholt, N., Cole, M., Herrling, M.P., Hess, M.C., Ivleva, N.P., Lusher, A.L., Wagner, M., 2019. Are We Speaking the Same Language? Recommendations for a Definition and Categorization Framework for Plastic Debris. Environmental Science \& Technology 53, 1039-1047.

He, Y., Men, B., Yang, X., Li, Y., Xu, H., Wang, D., 2017. Investigation of heavy metals release from sediment with bioturbation/bioirrigation. Chemosphere 184, 235-243.

IMO, 2018. International Convention on the Control of Harmful Anti-fouling Systems on Ships. Jeong, C.-B., Won, E.-J., Kang, H.-M., Lee, M.-C., Hwang, D.-S., Hwang, U.-K., Zhou, B., Souissi, S., Lee, S.-J., Lee, J.-S., 2016. Microplastic Size-Dependent Toxicity, Oxidative Stress Induction, and p-JNK and p-p38 Activation in the Monogonont Rotifer (Brachionus koreanus). Environmental science \& technology 50, 8849-8857.

Kalman, J., Palais, F., Amiard, J., Mouneyrac, C., Muntz, A., Blasco, J., Riba, I., Amiard-Triquet, C., 2009. Assessment of the health status of populations of the ragworm Nereis diversicolor using biomarkers at different levels of biological organisation. Marine Ecology Progress Series 393, 55-67. 
569

570

571

572

573

574

575

576

577

578

579

580

581

582

583

584

585

586

587

588

589

590

591

592

593

594

595

596

597

598

599

600

601

602

603

604

605

606

607

608

609

610

611

612

613

614

615

616

617

618

Karlsson, J., Eklund, B., 2004. New biocide-free anti-fouling paints are toxic. Marine Pollution Bulletin 49, 456-464.

Karlsson, J., Ytreberg, E., Eklund, B., 2010. Toxicity of anti-fouling paints for use on ships and leisure boats to non-target organisms representing three trophic levels. Environmental Pollution 158, 681-687.

Katranitsas, A., Castritsi-Catharios, J., Persoone, G., 2003. The effects of a copper-based antifouling paint on mortality and enzymatic activity of a non-target marine organism. Marine Pollution Bulletin 46, 1491-1494.

Liu, K., Wang, X., Wei, N., Song, Z., Li, D., 2019. Accurate quantification and transport estimation of suspended atmospheric microplastics in megacities: implications for human health. Environment international 132, 105127.

Maltby, L., Kedwards, T.J., Forbes, V.E., Grasman, K., Kammenga, J.E., Munns Jr, W.R., Ringwood, A.H., Weis, J.S., Wood, S.N., 2001. Linking Individual-level Responses and Population-level Consequences, in: Baird, D.J., Allen Burton, G. (Eds.), Ecological Variability: Separating Natural from Anthropogenic Causes of Ecosystem Impairment. SETAC, Pensacola, pp. 27-78.

Markets, M.a., 2016. Antifouling Paints and Coatings Market by Type (Copper-Based, SelfPolishing, Hybrid, Others), Application (Shipping Vessels, Drilling Rigs \& Production Platforms, Others), Region (APAC, Europe, North America, MEA, Latin America) - Global Forecast to 2021.

Møhlenberg, F., Kiørboe, T., 1983. Burrowing and avoidance behaviour in marine organisms exposed to pesticide-contaminated sediment. Marine Pollution Bulletin 14, 57-60.

Molino, C., Angeletti, D., Oldham, V.E., Goodbody-Gringley, G., Buck, K.N., 2019. Effect of marine antifouling paint particles waste on survival of natural Bermuda copepod communities. Marine pollution bulletin 149, 110492.

Moreira, S.M., Lima, I., Ribeiro, R., Guilhermino, L., 2006. Effects of estuarine sediment contamination on feeding and on key physiological functions of the polychaete Hediste diversicolor: Laboratory and in situ assays. Aquatic Toxicology 78, 186-201.

Moreira, S.M., Moreira-Santos, M., Guilhermino, L., Ribeiro, R., 2005. A short-term sublethal in situ toxicity assay with hediste diversicolor (polychaeta) for estuarine sediments based on postexposure feeding. Environmental Toxicology and Chemistry 24, 2010-2018.

Mouneyrac, C., Mastain, O., Amiard, J., Amiard-Triquet, C., Beaunier, P., Jeantet, A.Y., Smith, B., Rainbow, P., 2003. Trace-metal detoxification and tolerance of the estuarine worm Hediste diversicolor chronically exposed in their environment. International Journal on Life in Oceans and Coastal Waters 143, 731-744.

Muller-Karanassos, C., Turner, A., Arundel, W., Vance, T., Lindeque, P.K., Cole, M., 2019. Antifouling paint particles in intertidal estuarine sediments from southwest England and their ingestion by the harbour ragworm, Hediste diversicolor. Environmental Pollution 249, 163-170. Näkki, P., Setälä, O., Lehtiniemi, M., 2017. Bioturbation transports secondary microplastics to deeper layers in soft marine sediments of the northern Baltic Sea. Marine pollution bulletin 119, 255-261.

Naylor, G.P.L., 1987. The responses of cockles to heavy metal pollution and their use in the study of metal to metal uptake interactions. University of Manchester.

Nurioglu, A.G., Esteves, A.C.C., De With, G., 2015. Non- toxic, non- biocide- release antifouling coatings based on molecular structure design for marine applications. Journal of Materials Chemistry B 3, 6547-6570.

Poirier, L., Berthet, B., Amiard, J.-C., Jeantet, A.-Y., Amiard-Triquet, C., 2006. A suitable model for the biomonitoring of trace metal bioavailabilities in estuarine sediments: the annelid polychaete Nereis diversicolor. Journal of the Marine Biological Association of the United Kingdom 86, 71-82. 
R, 2019. R: A language and environment for statistical computing. , R Foundation for Statistical

\section{Computing, 3.6.0 ed, Vienna, Austria.}

Rainbow, P.S., 2007. Trace metal bioaccumulation: Models, metabolic availability and toxicity. Environment International 33, 576-582.

Rees, A.B., Turner, A., Comber, S., 2014. Metal contamination of sediment by paint peeling from abandoned boats, with particular reference to lead. Science of the Total Environment 494495, 313-319.

Rochman, C.M., Brookson, C., Bikker, J., Djuric, N., Earn, A., Bucci, K., Athey, S., Huntington, A., Mcllwraith, H., Munno, K., De Frond, H., Kolomijeca, A., Erdle, L., Grbic, J., Bayoumi, M., Borrelle, S.B., Wu, T., Santoro, S., Werbowski, L.M., Zhu, X., Giles, R.K., Hamilton, B.M., Thaysen, C., Kaura, A., Klasios, N., Ead, L., Kim, J., Sherlock, C., Ho, A., Hung, C., 2019. Rethinking microplastics as a diverse contaminant suite. Environmental Toxicology and Chemistry 38, 703-711.

Romano, C., Sarà, G., Salvo, G., Bishop, J., Mazzola, A., Widdows, J., 2011. Effect of the presence of the shore crab, Carcinus maenas, on burrowing behaviour and clearance rate of the common cockle, Cerastoderma edule. Marine Biology 158, 2685-2694.

Sandberg, J., Odnevall Wallinder, I., Leygraf, C., Virta, M., 2007. Release and chemical speciation of copper from anti-fouling paints with different active copper compounds in artificial seawater. Materials and Corrosion 58, 165-172.

Sapozhnikova, Y., Wirth, E., Schiff, K., Fulton, M., 2013. Antifouling biocides in water and sediments from California marinas. Marine Pollution Bulletin 69, 189-194.

Setälä, O., Lehtiniemi, M., Coppock, R., Cole, M., 2018. Microplastics in marine food webs, Microplastic contamination in aquatic environments. Elsevier, pp. 339-363.

Singh, N., Turner, A., 2009a. Leaching of copper and zinc from spent antifouling paint particles. Environmental Pollution 157, 371-376.

Singh, N., Turner, A., 2009b. Trace metals in antifouling paint particles and their heterogeneous contamination of coastal sediments. Marine Pollution Bulletin 58, 559-564.

Solé, M., Kopecka-Pilarczyk, J., Blasco, J., 2009. Pollution biomarkers in two estuarine invertebrates, Nereis diversicolor and Scrobicularia plana, from a Marsh ecosystem in SW Spain. Environment International 35, 523-531.

Soroldoni, S., Abreu, F., Castro, Í.B., Duarte, F.A., Pinho, G.L.L., 2017. Are antifouling paint particles a continuous source of toxic chemicals to the marine environment? Journal of Hazardous Materials 330, 76-82.

Soroldoni, S., Castro, Í.B., Abreu, F., Duarte, F.A., Choueri, R.B., Möller, O.O., Fillmann, G., Pinho, G.L.L., 2018a. Antifouling paint particles: Sources, occurrence, composition and dynamics. Water Research 137, 47-56.

Soroldoni, S., da Silva, S.V., Castro, Í.B., Martins, C.d.M.G., Pinho, G.L.L., 2020. Antifouling paint particles cause toxicity to benthic organisms: Effects on two species with different feeding modes. Chemosphere 238, 124610.

Soroldoni, S., Martins, S.E., Castro, I.B., Pinho, G.L.L., 2018b. Potential ecotoxicity of metals leached from antifouling paint particles under different salinities. Ecotoxicology and Environmental Safety 148, 447-452.

Thit, A., Banta, G.T., Selck, H., 2015. Bioaccumulation, subcellular distribution and toxicity of sediment-associated copper in the ragworm Nereis diversicolor: The relative importance of aqueous copper, copper oxide nanoparticles and microparticles. Environmental Pollution 202, 50-57.

Thomas, K.V., McHugh, M., Hilton, M., Waldock, M., 2003. Increased persistence of antifouling paint biocides when associated with paint particles. Environmental Pollution 123, 153-161. Thompson, I., Richardson, C., 1993. The response of the common cockle, Cerastoderma edule, to simulated chlorination procedures. Biofouling 7, 299-312. 
Toben, M., 2017. Microplastic pollution originating from Textiles and Paints: Environmental impacts and solutions. Coalition Clean Baltic (CCB), Uppsala, Sweden.

671 Tolhurst, L.E., Barry, J., Dyer, R.A., Thomas, K.V., 2007. The effect of resuspending sediment contaminated with antifouling paint particles containing Irgarol 1051 on the marine macrophyte

Ulva intestinalis. Chemosphere 68, 1519-1524.

674 Turner, A., 2010. Marine pollution from antifouling paint particles. Marine Pollution Bulletin 60, $675 \quad 159-171$.

676 Turner, A., Barrett, M., Brown, M.T., 2009. Processing of antifouling paint particles by Mytilus 677 edulis. Environmental Pollution 157, 215-220.

678 Turner, A., Singh, N., Millard, L., 2008. Bioaccessibility and bioavailability of $\mathrm{Cu}$ and $\mathrm{Zn}$ in 679 sediment contaminated by antifouling paint residues. Environmental Science \& Technology 42, 6808740.

681 UNEP, 1999. Manual on the biomarkers recommended for the MED POL biomonitoring 682 programme, Athens.

683 Viarengo, A., Ponzano, E., Dondero, F., Fabbri, R., 1997. A simple spectrophotometric method 684 for metallothionein evaluation in marine organisms: an application to Mediterranean and

685 Antarctic molluscs. Marine Environmental Research 44, 69-84.

686 Watermann, B.T., Daehne, B., Sievers, S., Dannenberg, R., Overbeke, J.C., Klijnstra, J.W., 687 Heemken, O., 2005. Bioassays and selected chemical analysis of biocide-free antifouling 688 coatings. Chemosphere 60, 1530-1541.

689 Wright, S.L., Rowe, D., Thompson, R.C., Galloway, T.S., 2013. Microplastic ingestion 690 decreases energy reserves in marine worms. Current Biology 23, R1031-R1033.

691 Yebra, D.M., Kiil, S., Dam-Johansen, K., 2004. Antifouling technology—past, present and future 692 steps towards efficient and environmentally friendly antifouling coatings. Progress in Organic 693 Coatings 50, 75-104.

694 Ytreberg, E., Karlsson, J., Eklund, B., 2010. Comparison of toxicity and release rates of Cu and $695 \mathrm{Zn}$ from anti-fouling paints leached in natural and artificial brackish seawater. Science of the 696 Total Environment 408, 2459-2466.

697 